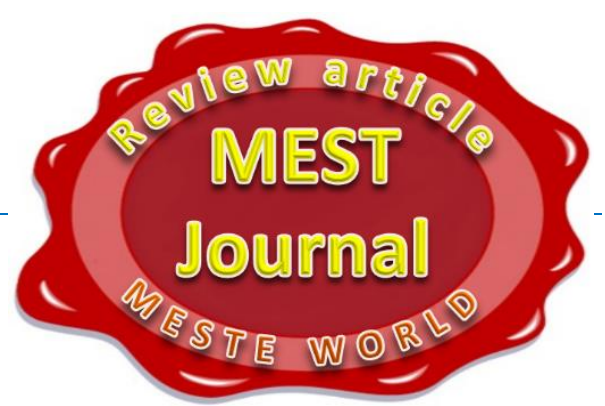

\title{
SUMMARY FUNCTIONAL ANALYSIS AND EVALUATION OF UNIVERSITY INFORMATION SYSTEMS AT "TODOR KABLESHKOV" UNIVERSITY OF TRANSPORT
}

\section{Dimitar Dimitrov}

"Todor Kableshkov" University of Transport, Department of Technology, Sofia, Bulgaria

\section{Nina Gergova}

"Todor Kableshkov" University of Transport, Department of Economics and Accountancy in Transport, Sofia, Bulgaria

\section{CMESTE}

JEL Category: 121, 123, L86

\begin{abstract}
The development of the university information systems has as its main purpose the coverage of the processes for providing the educational and scientific process, the administrative, the economic and other activities related to the work of the university. The overall process involved in conducting the training of the students includes the maintenance of a database of students and lecturers, which reflects on all the events during their stay at the university. This includes their personal data. In the case with the students, this is data related to the events of credentials, assessments, etc., and for the lecturers, this is their workload in hours, committees, bachelor or master thesis defense, scientific reports, etc. Finally, there are additional commitments in business activities as well as technical maintenance of university buildings and facilities. In practice, it is very difficult and expensive to build and maintain only one single system that automates all processes. Generally, a basic information system is being developed, and many other parallel systems are integrated, which integrate and interact with each other. In this publication, a functional analysis and evaluation of the implemented and used university information systems are developed for ensuring the processes at "Todor Kableshkov" University of Transport, Bulgaria. Classification of these information systems has been made depending on their functionality and purpose. The basic features and functional scope of the

Address of the corresponding author: embedded information systems are also given.
\end{abstract}

Dimitar Dimitrov

莑=”ddimitrov@vtu.bg 
Keywords: information system, university, enterprise resource planning, learning, scientific, business activities, website

\section{INTRODUCTION}

The success of universities in nowadays global conditions of competition, dynamic environment and rapid change is increasingly dependent on the introduction of innovations and new technologies for more effective management and training. Managing activities at a university is a complex task in itself, characterized by many traditional and specific processes aimed at organizing the teaching and research work in it. The development of the university information systems has as its main purpose the coverage of these processes to ensure the quality of the educational and research process, the administrative and the economic and other activities related to the work of the university. In practice, it is very difficult and expensive to build and maintain only one single system that automates all processes [ (VTU, 2014A), (VTU, 2014B), (Hristova \& Hristov, 2016)].

One such example is accounting systems, as the accounting process is rather complicated and specialized. This leads to the use of a standard accounting system and its link to other systems through the appropriate interface or automated data sharing or business logic sharing procedures.

Generally, a basic information system is being developed, and many other parallel systems are integrated, which integrate and interact with each other.

The present article analyzes and assesses the implemented and used university information systems to ensure the quality of the processes at the Todor Kableshkov University of Transport. Further, classification of these information systems is made depending on their functionality and purpose. The main features and functional scope of the embedded information systems are given.

The quality in higher education depends on the objectives and tasks of higher education institutions and users of educational services (learners, employers, families, and the country), as well as the ever-changing learner requirements that change in the learning process.
Quality is better if the difference between the results of the activities of the higher schools and the changing requirements of the learners is reduced.

\section{GENERAL MODEL FOR WORK AT THE UNIVERSITY}

The general model of the university's work includes three main areas of activity and reflects the overall business processes of learning and research and business that are under constant interaction. Fig. 1 shows the interaction of the different directions of the activities characterizing the work at the university.

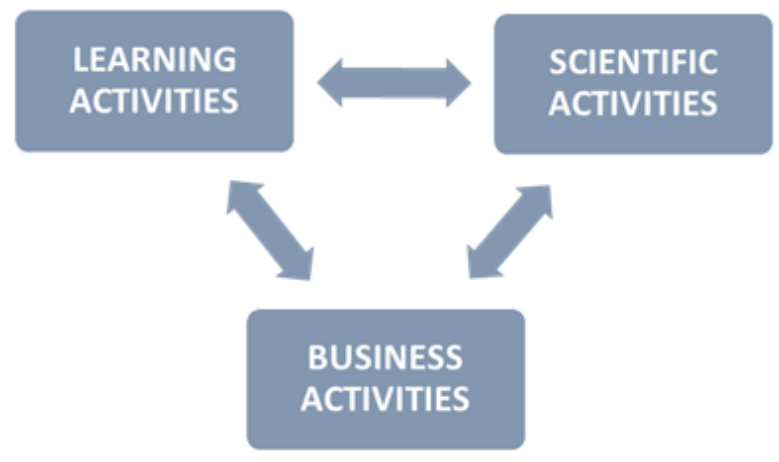

Fig. 1 Main directions of the activities characterizing the university processes

The first two are of a specific nature, whereas business is rather universal in nature and is described by standard methods and means of financial and monetary operations. Each of these elements lends itself to automation and information provision and service. The automation process allows three relatively independent core modules to be built and bound to solve the tasks in the different directions

Learning activities include the following elements:

- Candidate preparation;

- Higher education - Bachelor, Master and Ph.D. students;

- Additional vocational education postgraduate qualification, additional qualification, and courses.

The main features associated with the "Learning Activities" module relate to the organization of the 
learning process (schedules, plans and timetables), access to training sessions and materials (net meeting, digitized ones, electronic ones and multimedia), registration of the acquired knowledge by learners (self-study, tests, exams) and assessment of knowledge and skills.

The developed "Learning module" has the task of facilitating the collection of information from different sources that characterize the quality of training (lecturers, students, business, and experts), automating the process of processing and interpreting information about the individual learning process parameters. This is a module that targets learners and supports mentoring of teachers.

Research activities include the following elements:

- Creation of scientific production;

- Consulting;

- Patent development;

- Expertise;

- Reviewing;

- Development and implementation of projects;

- Organizing and conducting scientific conferences, forums, roundtables, etc.

The module "Scientific Activities" is related to organizing and conducting activities for the development of innovative and scientific skills related to the professional development of the teaching staff and a part of the students interested in science. Essentially, automation is associated with the development or deployment of ready-to-use information systems supporting research, as well as the registration of scientific forums, conferences, sessions, discussions, sharing meetings and exchange of experience. An essential element of this module is the collection and reporting of quantitative progress for appraisal and academic development of teaching staff.

The module "Business Activities" aims to organize other business activities from direct manufacturing, renting, etc., as well as financial resources from the other two modules in the form of costs, fees, profits, donations, etc. A substantial part of it is the systems of accounting for revenue and expenditure, management of material resources, services offered, etc.

\section{UNIFORM INFORMATION SYSTEM FOR THE MANAGEMENT OF THE MAIN UNIVERSITY ACTIVITIES}

The Unified Information System (EISU) has the task of facilitating the gathering of information from different sources for monitoring, measuring and analyzing the set of significant features. This information should provide an objective and impartial assessment of the quality of the individual strands of activities characterizing the work at the university. This will help to take management decisions in the short and long term, which will lead to the overall improvement of the university's activity and increase its competitiveness.

Through these systems, most of the university activities are automated and staff, students, and employees are assisted in fulfilling their core tasks. The developed information system is built on a modular principle and reflects the overall business processes related to the educational and research and business activities at the university [ (VTU, 2014A), (Dimitrov, 2014), (Dimitrov \& Vasilev, Functional Analysis of Newly Integrated Information System of Management of Todor Kableshkov University of Transport, 2013), (Dimitrov D. , 2013), (n.d., 2018)]. The main modules of EISU are:

- Student Admission. Provides the admission campaign throughout the active period. It is divided into two sessions: The first one is called a preliminary admission in which the prospective candidates do not have all the necessary application documents and are accepted conditionally. The second session takes place after the necessary documents have been collected and it includes a selection system for candidates. The longerterm motivates candidates to better explore the university's capabilities and the specifics of the professions they will acquire and will be more motivated to work in their chosen field.

- Student. This module contains everything you need to register the states, fees, activities, and assessments of the acquired knowledge and skills (student's electronic file). It facilitates the work with so-called 
master books and supports the final design of the diplomas.

- Teacher. Module for registering the teaching and research activities of lecturers. In particular, the teacher recognizes his work on the implementation of the training and assessment of the students through so-called electronic protocols. It also reports its research activity (publications, projects, portfolio, etc.), which are subject to reports of attestation, accreditation, etc.

- Ph.D. Student. Here the application process, the training plan and the graduation of the Ph.D. students (the Ph.D. student's electronic file) are registered.

- Education Department. Contains resource nomenclature (study rooms and laboratories), curriculums and programs, etc. necessary for the automated planning and reporting of the learning process (lectures, teacher and student groups and flows). An essential element is the system of calendar planning of the learning process itself. This module has interfaces for preparing online reports on the activities of individual groups (lecturers and students).

- Attestation. Specialized module for the management of the processes of attestation of the academic staff of the university. There is a direct dependence on student and teacher modules to generate reports and reports.

- Human Resources. This module contains the so-called "labor file" of teachers and employees. The object of automation is the employment contracts and the reporting of the internship and the changes related to it. These data are the basis of some of the other modules, including user registrations and access rights in the EISU module that was last described.

- Business Activities. This is a specific module for accounting for revenue and expense for renting part of the University's infrastructure property. In the income part are mainly the rents, and in the part costs, there are the consumables used by the tenants.

- Billing. Registration and reporting of payments by students, tenants, and companies on cash and non-cash way.
- Buyer profile. This module manages the public procurement cycle under Public Procurement Law, as well as auctions under state property law.

- Documents. Information module for management and visualization of the internal documents for the work of the individual management units, faculty councils, and the academic council, etc.

- Settings. An official tool to the system that manages user registrations, roles, and access rights to individual EISU functionalities and screens.

Thus, constructed modules cover the main processes and business logic of university processes. A basic principle that has been respected in designing and programming the system was to put each piece of information into the module that is most appropriate and to use it in the rest, and just to build and complement it. Some of the specifics for details and management of the lower level processes (example- the e-learning system and the other systems described below) proved to be quite complex as organization and business logic and therefore the model for using ready- commercial or open source systems that have been integrated with EISU via data link and data transfer modules, allowing individual systems to operate in electronic communication and symbiosis mode.

\section{SYSTEM FOR ELECTRONIC AND DISTANCE LEARNING}

The e-learning and distance-learning system is an open source Moodle based information system that implements both publishing and delivering of e-learning materials to students and conducting ongoing monitoring and assessment of acquired knowledge and skills [ (VTU, 2014B), (Kolev, Todorova, \& Gergova, 2012), (VTU-Sofia, 2018), (VTU-moodle, 2018)]. Although there are more advanced systems in the information market, some of which are extremely expensive, this system now largely covers our requirements for such a system. There is a link to the EISU, which imports active students and groups who have access to individual e-courses. 


\section{LIBRARY INFORMATION SYSTEM}

The library information system is a commercial specialized electronic system that is embedded in the university network (VTU, 2014B). Its characteristic is that it contains two modules:

- Reader module for management of the use of literature in paper form - electronic card of the reader. This module has communication with the data from a student module of EISU.

- A web module for previewing library titles as part of the book fund that is not available, digitized and can be used (e-lib_vtu, 2018).

A major advantage is that this system can also be used remotely, and textbooks and books in electronic form become part of the e-learning and distance learning system.

\section{ACCOUNTING, ADMINISTRATIVE, INFORMATION, LEGAL AND OTHER SYSTEMS}

The specifics of accounting, administrative work, warehousing etc., have made it necessary to use a number of specialized software with professional support and improvement, and for them, there have been developed tools for the EISU, through which data are most often transmitted by the EISU to them. The most important systems are commercial:

- Accounting system containing a comprehensive accounting management mechanism at the university. There is a connection with the EISU and the system "Hotel".

- Hotel - a system for registering rental rates and payments for the students and tenants in the dormitory and hotel part. There is a link with EISU to track student status and fee setting.

- Document flow management system.

- Warehouse management and asset management system.

- System for use of legal regulations.

- Salaries, fees, health and pension insurance, etc.

All these systems work in sync and exchange mode of relevant data. They represent the general information-advisory resource and are used by the university administration.

\section{UNIVERSITY INFORMATION WEB SITES}

University websites are the "tip of the iceberg" in terms of information provision and integration of all university systems and activities.

Firstly, the main information site (http://www.vtu.bg/) is organized to visualize all activities and actions (VTU-Sofia, 2018). Most of the systems listed above have a web interface, and through hyperlinks and links the user goes through the different systems, and for some systems, this is realized through frames that give the impression that we are still on the university site, and in fact, it is an aggregated element of another information system.

Other sites are so-called department sites and other units that have been developed as standalone projects and allow departments that have such sites to manage them autonomously. In most cases, the common *.vtu.bg domain is used, where the "*" symbol is the subdomain name of the site. For example, behind mail.vtu.bg is the service and Web interface for managing and checking corporate e-mail (mail.vtu, 2018).

\section{CONCLUSIONS}

In this article, a summary functional analysis and evaluation of the implemented and used university information systems was carried out, which automated the processes at "Todor Kableshkov" University of Transport. These systems are classified according to their functionality and purpose. Their main features and functional range are also presented.

The implementation of the Unified Information System (EISU) provides:

\footnotetext{
- easy access to information between organizational units, preparation of reports, etc.;

- reducing the time and cost of organizing administrative and financial activities;

- introducing new, less risk-prone approaches to the organization of certain activities;

- improving the activities and satisfying the needs and the requirements of consumers;
} 
- researching and analyzing the competitive advantages of the university;

- establishing reliable information to support university management;

- optimizing the short and long-term goals of the university and achieving competitive advantages.
The implemented unified information system leads to a qualitative change in the interaction and service of the users of the systems, improves the overall activity of the university and enhances its competitiveness in the educational market.

\section{WORKS CITED}

Dimitrov, D. (2013). The Newly Developed Project of Integrated Information System of Management in the Todor Kableshkov University of Transport. Proceedings of the International Conference on Application of Information and Communication, Technology and Statistics in Economy and Education - ICAICTSEE-2013. Sofia: UNWE.

Dimitrov, D. (2014). Summary Analytical Model of the Newly Developed Integrated Information System for Management of "Todor Kableshkov" University of Transport. Scientific Forum of the Faculty of Transportation Management. Borovets: VTU "Todor Kableshkov".

Dimitrov, D., \& Vasilev, D. (2013). Functional Analysis of Newly Integrated Information System of Management of Todor Kableshkov University of Transport. XXI International Scientific Conference "TRANSPORT 2013", Mechanics, transport, communications (pp. IV-7-11). Borovec: VTU "Todor Kableshkov".

e-lib_vtu. (2018, May 30). Website of the electronic library catalog of "Todor Kableshkov" University of Transport. Retrieved from VTU "Todor Kableshkov": http://e-lib.vtu.bg/

Hristova, M., \& Hristov, H. (2016, July 15). University Management Stimulating Higher Education Quality. MEST Journal, 4(2), 103-112. doi:10.12709/mest.04.04.02.11

Kolev, P., Todorova, D., \& Gergova, N. (2012). Electronic Forms of Training - Opportunities and Prospects for "Todor Kableshkov" University of Transport. International Scientific Conference "Management 2012" (pp. 343-369). Belgrade: ICIM Plus.

mail.vtu. (2018, May 30). Corporate mail of "Todor Kableshkov" University of Transport. Retrieved from VTU "Todor Kableshkov": http://mail.vtu.bg/

n.d. (2018, May 30). Unified information system of "Todor Kableshkov" University of Transport. Retrieved from VTU "Todor Kableshkov": http://eisu.vtu.bg/

VTU. (2014A). Documentation on project BG051P0001-3.1.08-0007 "Improving the effectiveness of the educational process by improving the quality management systems for education and training services at Todor Kableshkov University of Transport". Sofia: VTU "Todor Kableshkov".

VTU. (2014B). Documentation on project BG051P0001-4.3.04-0024 "Development of electronic forms of distance learning and construction of "Virtual library" at the Todor Kableshkov University of Transport". Sofia: VTU "Todor Kableshkov".

VTU-moodle. (2018, May 30). Electronic and Distance Learning System of "Todor Kableshkov" University of Transport. Retrieved from VTU "Todor Kableshkov": http://moodle.vtu.bg/

VTU-Sofia. (2018, May 30). The homepage of the "Todor Kableshkov" University of Transport. Retrieved from VTU: http://www.vtu.bg/

Received for publication:

Revision received:

16.04 .2018

Accepted for publication:
22.05.2018

07.06.2018 


\section{How to cite this article?}

Style - APA Sixth Edition:

Dimitrov, D., \& Gergova, N. (2018, July 15). Summary Functional Analysis and Evaluation of University Information Systems at "Todor Kableshkov" University of Transport. (Z. Cekerevac, Ed.) MEST Journal, 6(2), 48-54. doi:10.12709/mest.06.06.02.06

Style - Chicago Sixteenth Edition:

Dimitrov, Dimitar, and Nina Gergova. 2018. "Summary Functional Analysis and Evaluation of University Information Systems at "Todor Kableshkov" University of Transport." Edited by Zoran Cekerevac. MEST Journal 6 (2): 48-54. doi:10.12709/mest.06.06.02.06.

Style - GOST Name Sort:

Dimitrov Dimitar and Gergova Nina Summary Functional Analysis and Evaluation of University Information Systems at "Todor Kableshkov" University of Transport [Journal] // MEST Journal / ed. Cekerevac Zoran. - Toronto : [s.n.], July 15, 2018. - 2 : Vol. 6. - pp. 48-54.

Style - Harvard Anglia:

Dimitrov, D. \& Gergova, N., 2018. Summary Functional Analysis and Evaluation of University Information Systems at "Todor Kableshkov" University of Transport. MEST Journal, 15 July, 6(2), pp. 48-54.

Style - ISO 690 Numerical Reference:

Summary Functional Analysis and Evaluation of University Information Systems at "Todor Kableshkov" University of Transport. Dimitrov, Dimitar and Gergova, Nina. [ed.] Zoran Cekerevac. 2, Toronto : s.n., July 15, 2018, MEST Journal, Vol. 6, pp. 48-54. 